\title{
To End Child Witchcraft Accusations, A Task for the Whole Church
}

\author{
Maïmouna Jessica Obot
}

"What can we do to end this?" This is the question that has occupied my mind ever since I first heard about children being accused as witches in the Nigerian churches. Together with friends in Germany and in Nigeria I set out to help end child witchcraft accusations in Nigeria under the umbrella of the NGO "Storychangers e.V.". We carry out pastoral seminars where we teach about child development, Jesus' view of children and about what the Bible has to say about witchcraft-and what not. Our hope is that the pastors attending would disseminate the message and bring about change in their churches, in their villages and in the whole country.

Reactions to this endeavour are mixed. Although many are supportive of this endeavour, there is quite a number of people who say: "Let Africa solve her own problems! Europeans and Americans alike have done enough harm, Africa doesn't need another 'White Saviour'!" Others say: "This is a problem which does not affect us at all. Why bother?"

The history of missions in Africa has many sides and there are quite a few dark ones. Many European missionaries entertained thoughts of cultural superiority of "the old world" and deemed everything "native" as evil and inferior. There was no sensitivity towards the culture and mentality of the African peoples which resulted in Western-style problem-solving only creating new problems in and for Africa. It is therefore quite understandable that the thought of a German NGO working on the ground in South-West Nigeria would cause rejection at first. The second uttering, however, always rings as a jangling discord in my ears, especially when it is issued by people associated with the Christian faith. As Christians, we may not avert our gaze and look the other way. The church in Nigeria and in other African countries suffers under the false preaching of those who declare that all evil stems from bewitchment. The church is the body of Christ and Christ is one. When one part suffers, the whole body suffers. We are to grieve with those who grieve and to consider ourselves fellow prisoners with those incarcerated. There is no way that we could ever rightfully say that this problem does not affect us, because it does.

The worldwide church of Jesus Christ has got to tackle the task of combatting the wrong doctrine of child witches and lock arms with the brothers and sisters in Africa. However, this must be done not with a spirit of superiority but with a spirit of humility. On fundraising events the first most frequently heard comment of our supporters in Germany is the following: "Unbelievable! They're still living in the Middle Ages! We have long overcome this!" This comment always makes me flinch. Most of the time it is enough to remind my listeners of Germany's not-so-glorious recent past and ask them if they think that killing a child because someone has called him or her a witch is worse than killing a child just because he or she is Jewish? This question then inevitably makes the other side flinch.

We will always be able to find both good and evil in the history of our nations. Both are there to teach us, and once we have learned our lesson we are to comfort others $\left(2^{\text {nd }}\right.$ Cor $\left.1: 4\right)$. When I looked at the history of my native south-west Germany, I was shocked to find out that it had once been a hotspot of child witchcraft accusations, starting in the $17^{\text {th }}$ century, long after the Middle Ages had waved goodbye (See for a detailed account of the major trials: Weber 1996). Children had to attend week-long judicial trials, undergo torture, and were at times burned at the stake on the charge of witchcraft. This era is rarely commented on in history textbooks or in TV documentaries because it seems to be an outlandish thing that our ancestors would persecute children, torture them, and sentence them to death on account of witchcraft accusations well up until the $19^{\text {th }}$ century. Thus, although Nigeria and Germany seem to be worlds apart, these two countries have a lot in common.

\footnotetext{
1 The letters „e.V.“ stand for "eingetragener Verein“ which is a title conferred to associations that were granted the status of membership corporation under German law.
} 
The German witch hunt and the Nigerian witch hunt have a lot in common, but then, are also very different. For example, the German "child witches" in the overwhelming majority of cases accused themselves of the crime of witchcraft, thus issuing their own death sentence. However, I have never heard of a Nigerian "child witch" who has handed in herself or himself. Also, the German witchcraft trials were worldly court hearings; in the case of Nigeria it is informal church gatherings, town hall meetings of the community, or simple family gatherings.

These obvious differences, as well as the epochal and geographical divide tell us that we won't be able to use any approach to combatting torture and murder in the name of fighting witchcraft as a blueprint for any efforts undertaken in modern-day Africa. But they can still serve as a reservoir of ideas and possible starting points.

The end of German witchcraft accusations was signalled, amongst others, by the writings of Friedrich von Spee (Spee and Ritter 1982), a Jesuit and Christian Thomasius, professor of law at the University of Halle (Thomasius 1701). As early as 1631 von Spee questioned the validity of evidence obtained under torture, which was also a common feature of witchcraft trials. Since witchcraft cannot be proven, he reasoned, no one should be sentenced for it. By doing this, von Spee sowed the seed of doubt.

In our pastoral seminars, we as Storychangers e.V. also intend to cast doubt on the supposed evidence brought forth by the children's accusers. Oftentimes it is bed-wetting that is thought of as a "clear sign" of child witches in the Nigerian context. We explain all possible physical and psychological causes of bed-wetting and thus shed doubt on the supposed spiritual cause, that is, witchcraft.

Seventy years after von Spee, Thomasius appealed to the adherents of the Enlightenment to please let reason rule. Reason and not conviction should be allowed in the courthouse, which would do away with all religion-based accusations, such as witchcraft. Both sparked a debate in the intellectual and clerical circles of their day that would end up being dinner table conversations. The phenomenon was finally talked about without fear and in an open atmosphere. Priest, Ngolo and Stabell's report (2020) is doing just the same by bringing this topic to the frontline of theological conversations. Theologians from all denominations and countries should pick up the conversation and break it down for their congregations. What is talked about cannot be ignored.

Regarding Thomasius' contribution, it should also be observed that he was not part of the church but was a jurist. Involving the worldly powers in the fight to end child witchcraft accusations might be a good idea, depending on the circumstances. In our Nigerian setting having the authorities support our activities is a guarantee for uninterrupted seminars and safety for the facilitators.

It is important to let oneself be humbled by the weight of one's own history in order to face the members of the suffering part of the Body as sisters and brothers in the fight, and not as recipients of sound doctrine emanating from the supposedly nobler parts of the world. Local partnership is key to the success of the endeavour. What in one place might be considered witchcraft, might well not be in another place and vice versa. Convictions vary tremendously and one must always make sure to address the problem of that particular people group.

It took about 50 years for the teachings of Thomasius to penetrate the whole of northern Germany and an extra 100 years for them to finally reach and influence minds in Germany's south-west. However, taking into account the speed in which information travels around the globe in the $21^{\text {t }}$ century as compared to the $18^{\text {th }}$ century, I am hopeful that the combined efforts of the church will bring about a change of mind on the whole continent within a matter of only a handful of years.

The contribution of Priest et al. is an important milestone in the fight against child witchcraft accusations. We have been enabled to look into the why, how and where of the phenomenon and have been equipped with the necessary data. My response to this report is: "Let's go and end the practice of child witchcraft accusations!" On the "how" of going, I hope to have shed some insightful remarks. It is my prayer that thousands will follow suit.

\section{References}

Spee, Friedrich v., and Joachim-Friedrich Ritter. 1982. Cautio Criminalis Oder Rechtliches Bedenken Wegen Der Hexenprozesse. Unveränd. Nachdr. [d. Ausg.] Weimar, Böhlau, 1939. Dtv.

Priest, Robert J., Abel Ngolo and Timothy Stabell. 2020. Christian Pastors and Alleged Child Witches in Kinshasa, DRC. On Knowing Humanity Journal 4(1):1-51.

Thomasius, Christian. 1701. De Crimine Magiae. http://www.hs-augsburg.de/ ${ }^{\sim}$ harsch/Chronologia/ Lspost17/Thomasius/tho_ma00.html. Accessed January $10^{\text {th }}, 2020$.

Weber, Hartwig. 1996. "Von der verführten Kinder Zauberei": Hexenprozesse gegen Kinder im alten Württemberg. Sigmaringen: Thorbecke. 


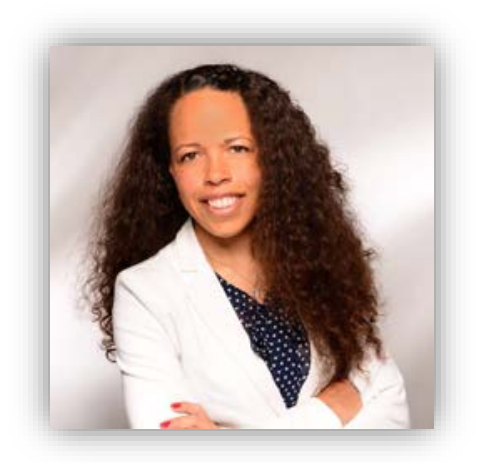

Maïmouna Jessica Obot is a fully qualified lawyer under German law and currently works as a legal advisor for the Regional Crime Investigation Unit of SouthWest Germany. She is a M.A. student of Culture and Theology at the European School of Culture and Theology in Korntal, Germany, a campus of Columbia International University, USA. Upon hearing about child witch hunts in Nigeria, Ms. Obot traveled to Nigeria in 2016 to see if what she had heard was actually true. The Nigerian church's major role in the witch hunts led her to found Storychangers e.V., a German NGO that fights against witchcraft accusations and supports the child victims. Together with her local partners, she carries out pastoral seminars to equip pastors who would like to take a stand against child witchcraft accusations.

Author email: maimouna.obot@gmail.com 